\title{
Caring for terminal AIDS patients: The eXPERIEnCES Of CAREgivers IN A PALLIATIVE CARE INSTITUTION
}

\author{
Authors: \\ Magdalena (Dalena) van \\ Rooyen $^{1}$ \\ Margaret Williams ${ }^{1}$ \\ Essie Ricks ${ }^{1}$

\begin{abstract}
Affiliations:
${ }^{1}$ Department of Nursing Science, Nelson Mandela Metropolitan University, South Africa
\end{abstract}

\section{Correspondence to:}

Dalena van Rooyen

\section{e-mail:}

dalena.vanrooyen@nmmu. ac.za

\section{Postal address:}

Department of Nursing Science, Nelson Mandela Metropolitan University, PO Box 77000, Port Elizabeth 6031, South Africa

\section{Keywords:}

AIDS patients; palliative care; care givers; hospices; terminal illness

\section{Dates:}

Received: 25 July 2008

Accepted: 23 Jan. 2009

Published: 29 June 2009

How to cite this article: Van Rooyen, D., Williams, M. \& Ricks, E., 2009,

'Caring for terminal AIDS patients: The experiences of caregivers in a palliative care institution', Health SA Gesondheid 14(1), Art. \#440, 11 pages. DOI: 10.4102/hsag.v14i1.440

\section{This article is available} at:

http://www.hsag.co.za (c) 2009. The Authors. Licensee: OpenJournals Publishing. This work is licensed under the Creative Commons Attribution License.

\section{ABSTRACT}

This research focused on the lived experiences of caregivers working with Acquired Immune Deficiency Syndrome patients, particularly patients who die from this disease whilst resident in a formal institution. A qualitative, exploratory, descriptive, and contextual research design with a phenomenological approach to inquiry was utilised. 13 unstructured interviews, which were audio-taped, were conducted with caregivers working full-time in a formal institution caring for patients who are dying from AIDS. The transcribed interviews were analysed using Tesch's method of descriptive analysis (in Creswell 1994:115).

One central theme emerged, namely that in their daily duty (at their place of work), caregivers experienced various challenges as a result of having to deal with the death of their patients suffering from AIDS, and five sub-themes were formulated from further analysis. The five sub-themes were:

- Caregivers experienced emotional challenges in caring for patients dying of AIDS

- Caregivers experienced a difference in death and dying of adults as opposed to children

- Caregivers experienced the rationalisation of death and dying differently

- Caregivers experienced that faith in God gives them strength to cope with death and dying

- Caregivers experienced caring for patients as fulfilling and meaningful to them despite the sadness of death and dying.

The participants face the death of their patients daily, from a disease that causes untold suffering to the patients, family members and to the caregivers themselves, who wish they could prevent the anguish, the pain and the inability of the medical profession to do more than they are at present towards curing this disease. They described their emotional experiences, which included the various challenges that they face as a result of having to deal with the death and dying of their patients suffering from AIDS. The information shared by these participants formed the foundation of the broad guidelines that were developed in order to provide support for such caregivers.

\section{OPSOMMING}

Die fokus van hierdie navorsing was op die beleefde ervaringe van die versorgers wat met Verworwe Immuniteitsgebreksindroom pasiënte werk, veral pasiënte wat sterf aan die siekte terwyl hulle in 'n formele inrigting is. ' $n$ Kwalitatiewe, eksploratiewe, beskrywende en kontekstuele navorsingsontwerp met 'n fenomenologiese benadering was gebruik. 13 ongestruktueërde onderhoude, wat op 'n audioband opgeneem was is gehou met versorgers wat voltyds in ' $n$ formele inrigting sorg vir pasiënte wat aan VIGS sterf werk. Tesch se metode van beskrywende analise was gebruik om die transkribeerde onderhoude te analiseer (in Cresswell 1994:115).

Een sentrale tema het na vore gekom, naamlik dat versorgers tydens die uitvoering van hulle daaglikse pligte (in die werk) ' $n$ verskeidenheid uitdagings ondervind het as gevolg van hul pasiënte wat sterf van VIGS en vyf sub-temas is geformuleer deur verdure analise. Hierdie vyf sub-temas was:

- Versorgers ervaar emosionele uitdagings tydings die versorging van pasiënte wat van VIGS sterf

- Versorgers ervaar $\mathrm{n}$ verskil in die dood en sterfte van volwassesnes teenoor die van kinders

- Versorgers ervaar die rasionaliseering van dood en sterfte verskillend

- Versorgers ervaar dat vertroue in God hulle krag gee om die dood en sterfte beter te hanteer

- Versorgers ervaar dat die versorging van pasiënte wat sterf of sterwend is vervullend is ten spyte van die hartseer van dood en sterfte.

Die deelnamers ervaar die dood van hul pasiënte daagliks van 'n siekte wat ongetelde lyding vir hulself, die pasiënt en hul familie veroorsaak. Die versorgers wens dat hulle kon die angs en die pyn voorkom, sowel as die ombekwaamheid van die mediese beroep om huidiglik meer te kan doen om die siekte te genees. Hulle beskryf hul emosionele ervaringe wat die verskillende uitdagings wat hul ervaar as gevolg van hul betrokkenheid by die dood en afsterwe van hul pasiënte aan VIGS. Die inligting wat deur hierdie deelnemers gedeel word, vorm die basis van die ontwikkeling van breë riglyne om die versorgers te ondersteun.

\section{INTRODUCTION}

An estimated 38.6 million people worldwide were living with the Auto Immune Deficiency Syndrome (AIDS) at the end of 2005 (UNAIDS 2006:6). This figure has not changed significantly to date. In South Africa, figures from antenatal studies estimate that 5.5 million people were living with AIDS in 2005, whereas a trend towards a gradual increase, compared to the current worldwide decrease in HIV prevalence, has been identified (UNAIDS 2006). Of further significance is the fact that increasing numbers of women are being infected, with young women (of 15 to 24 years) being three times more likely to be HIV positive than young men (UNAIDS 2006:9). 
Most AIDS care occurs within households and surrounding communities, with women providing care for those infected and affected, in addition to providing financial resources for the survival of the family (UNAIDS 2004:5). In other words, families, communities and governments tend to rely on the resilience of volunteers, mostly women, to tend to the sick, without providing any means of support for these caregivers. Most of these women who are caring for others, are frequently battling AIDS-related illnesses themselves (UNAIDS 2004:5). Furthermore, 'poverty and faltering public services in many areas are combining with AIDS to turn the care burden for women into a crisis' with farreaching social, health and economic consequences (UNAIDS 2004:15). What is becoming clear rapidly is that many households are physically, emotionally and financially ill-equipped to cope with the stresses of caring for critically ill and/or dying patients, and such patients are more frequently admitted to formal care institutions (i.e. hospitals and palliative care institutions).

Hospitals and hospices cannot cope with the influx of patients suffering from or dying of AIDS-related illnesses. Eaton and Etue (2002:162) confirm this, stating that 'the three cash-strapped Government Hospitals in the Port Elizabeth area are most often forced to turn adults, children and even babies with AIDS away to make space and resources available to those with curable ailments'. Theodosious (2005:1) provides further information by pointing to the fact that the patient ratios at Government facilities (in Port Elizabeth) occasionally average around 47 patients per nurse/caregiver.

The problems experienced by caregivers who nurse patients with AIDS in palliative care institutions are unique in that they have to mourn multiple losses. Studies have shown that survivors of multiple losses are afraid, or even unable, to grieve openly, since they fear losing control of their feelings. They tend to contain their feelings and even cover up with an outward display of coping and being fine, expressing no need for help and carrying on as usual. When discussing feelings, they tend to deny, intellectualise or shy away from sharing heart-felt feelings. The result of such stoicism would be symptoms similar to those seen with the 'burnout' syndrome: emotional numbing, withdrawal from others, misdirected anger and resorting to the use of drugs and/or alcohol (Alexander 2005:20). The experience of multiple losses due to AIDS might often be complicated further by the fact the caregiver may herself be infected and facing death (Alexander 2005:20).

Coping with patients (young and old) who are dying of AIDSrelated illnesses is hard, but it is even harder to watch children and babies suffering from this disease. AIDS patients suffer from more than one opportunistic infection in the final stages of the disease, and therefore need 24-hour care, often for weeks or months on end before they die. Incontinence of urine and faeces, breathlessness from chest complaints and skin diseases that cover $90 \%$ of the body are some of the problems facing patients and health caregivers (Evian 2000:97-120). The caregivers, even in formal institutions, rarely have received education beyond a Matriculation certificate and, perhaps, a three-month theoretical and practical course at an accredited academy for the training of caregivers. This is inadequate education for enabling these caregivers to cope with the type of work currently being required in a hospice dedicated to caring for AIDS patients. Thus coping with all the emotion and hardship surrounding them must be challenging for caregivers with limited training, who mostly come from disadvantaged backgrounds, and are in some instances lacking the most basic of life skills. Furthermore, caregivers' inability to cope with the concept of death, their own or that of another, and a struggle to talk about death may manifest in an attitude of 'not caring' from the side of the caregiver towards the patient and his/her relatives (Callanan \& Kelley 1992:34, 60-62). In addition, patients may not receive the kind of care they require when dying, often because the staff (caregivers) might not fully understand the magnitude of the terminal illness and of the dying experience as it affects patients and their families (Callanan \& Kelley 1992:32-33).

\section{PROBLEM STATEMENT}

From the foregoing discussion and from the observation of the researcher responsible for overseeing the fieldwork, who was previously employed in an institution where patients with AIDS were nursed, it was clear that caring for AIDS patients is challenging and eventually involves the experience of multiple losses. Caregivers seem ill-equipped for the tasks of caring for ill and dying AIDS patients, as well as for coping with the experience of multiple losses. Constantly facing death has the result that caregivers avoid internalising the death of patients, in order to avoid being overcome with grief, and cut themselves off emotionally or use denial as a defence mechanism (GoodsonDunlap 2004:43). The previous author also observed that caregivers appeared distant from their patients, which manifested as an uncaring or switched-off attitude. In addition, the caregivers would approach the researcher for counselling to assist them to cope with the continual loss they were experiencing, at home as well as at work, since many of the caregivers had also lost family members to AIDS, or were looking after family members with AIDS.

As a result of this, the researcher decided to embark on this research endeavour, with the following objectives in mind:

- To explore and describe how caregivers in a formal setting (an institution) experience caring for their patients dying from AIDS, and

- To develop broad guidelines that would enable the mentors of caregivers to provide support to the caregivers and enable them to optimise the nursing care of patients dying from AIDS.

From the above-mentioned problem statement, the following research questions were formulated to aid realisation of the stated objectives:

- How do caregivers experience caring for patients dying of AIDS?

- How can the caregivers be given adequate support in order to ensure optimum care of AIDS patients and their families?

\section{AIMS OF THE STUDY}

The aims of the study were to:

- Explore and describe how caregivers in a formal setting (a palliative care institution) experience caring for their patients dying from AIDS, and

- Develop broad guidelines that would enable the mentors of caregivers to be able to provide support to the caregivers, to enable them to optimise nursing care of patients dying from AIDS.

The key concepts of this study were as follows:

- Auto Immune Deficiency Syndrome (AIDS): This follows on from infection with the Human Immunodeficiency Virus (HIV), and is considered to be the final phase of HIV infection, progressing from the symptomatic phase of HIV.

- Death: 'The final cessation of vital functions in an organism; the ending of life' (Allen 1990:27). Death comes to everyone and therefore remains an important phenomenon in all cultures and with all people, religious or not, and is a concept to be feared, something not spoken about.

- The dying patient: For the purposes of this research, dying patients are considered to be those patients with end-stage AIDS.

- Palliative care: Palliative care is often referred to as comfort care and is primarily directed at providing relief to a terminally ill person through the management of symptoms and pain.

- Caregivers: Because there are so many AIDS patients, hospitalisation for those who are terminally ill is not an option. Most communities, therefore, are left with the burden of caring for a growing number of sick people. Caregivers are those who help to care for the sick, which they do once they have been trained in basic health care work. 


\section{- Experience:}

Experience refers to the sum total of an individual's thoughts and feelings and the things that have happened to an individual. It includes the internal environment (body, mind and spirit) as well as the external environment (physical, social and spiritual dimensions).

(Maritz 2003:11)

- Hospice: Considered to be a home-like alternative care setting, a hospice is designed specifically for the terminally ill to create an environment that is home-like, in which death may come to pass with dignity.

- Guidelines: 'Guide' refers to a 'directing principle or standard' (Allen 1990:525), therefore guidelines will enable caregivers to follow certain directions that are formulated to optimise patient care in the AIDS field.

- Support: In this context, support refers to support for caregivers, which would mean that they would receive moral and psychologist support from mentors.

\section{CONTEXT OF THE STUDY}

This study was conducted in the palliative care institution where the participants in the study worked; they were interviewed within the physical environment and cultural context in which they were working at the time.

\section{RESEARCH DESIGN AND METHOD}

The researcher chose a qualitative, exploratory, descriptive and contextual research design with a phenomenological approach to inquiry. The phenomenological approach to inquiry which, according to Crabtree and Miller (1999:28), aims at uncovering what it is to have a certain experience, was used to reflect the lived experiences of caregivers caring for their patients dying from AIDS in a formal setting (an institution). The study was conducted in two phases. Data were collected and analysed during the first phase, in which themes and sub-themes were identified. These were used to develop guidelines for practice during the second phase. This qualitative, explorative, descriptive and contextual research design was chosen to enable the researcher to reveal, through stories and reflections, the experiences of caregivers in an environment where patients with AIDS were being cared for because the topic of research involved a relatively unknown or under-researched area.

\section{DATA COLLECTION}

The research population consisted of caregivers working in a palliative care institution for patients dying of AIDS. Criterionbased purposive sampling was used in the recruitment of research participants. Purposive sampling is based on the assumption that the researcher's knowledge about a population can be used to hand-pick the participants to be included in the sample (Polit \& Hungler 1999:29). Criterion sampling works well when all of the individuals studied represent people who have experienced the phenomenon being studied (Creswell 1998:119). The criteria that had to be met for inclusion in the study required that participants:

- Had all worked at their place of work for more than a year

- Had all worked with patients dying of AIDS

- Had all worked with both adults and children dying from AIDS

- Were representative of different cultural groups according to South African demographics

- Were representative of different gender groups.

The researcher drew a purposive sample from the available caregivers who met the research population criteria. Those who agreed to participate were given an informed consent form to sign in the presence of the researcher and a witness.

The demographics of the participants were as follows:

- Five of the caregivers were over 50 years old, two were in their 40s, two in their 30s and the remaining four were in their mid-20s
- Five of the caregivers interviewed had achieved a Standard 10 certificate, two had completed school at the Standard 9 level, five at Standard 7 and one caregiver had only completed Standard 5

- 12 of the caregivers were females and one caregiver was male

- Six of the caregivers had more than five years of experience in the facility, while the remaining seven had between one and two years each.

Data were collected by means of unstructured interviews with one central question, namely: 'Can you tell me about your experiences of working with patients with AIDS?' The researcher overseeing the fieldwork arranged for the interviews to be conducted on a one-to-one basis in a room which was used for counselling purposes. A field worker was engaged to conduct the interviews because the researcher overseeing the fieldwork was part of the management at this institution and there was some concern that this factor would influence the responses of the participants. Interviews were audio-taped and transcribed verbatim. In addition, field notes were made of each interview. Interviews continued until data saturation occurred, which was demonstrated by the repetition of themes (Burns \& Grove 1997:348).

\section{DATA ANALYSIS}

The transcriptions and field notes formed the data base, or data set. The audio-taped interviews were transcribed verbatim within 24 hours following each interview. Data were analysed using the method of descriptive analysis proposed by Tesch (in Creswell 1994:155) where themes and sub-themes were identified by:

- Reading transcriptions and field notes repeatedly to form an overall impression

- Jotting down in the margins the main ideas that came to mind

- Compiling a list of topics

- Clustering similar topics together and grouping these into major, unique and leftover topics

- Encoding topics

- Generating descriptive wording for topics and turning them into categories

- Reducing topics by grouping those that were related (this serves as a basis for literature control)

- Finalising abbreviations used for each category

- Alphabetising these codes

- Assembling data according to categories and conducting a preliminary analysis

- Recoding existing data where necessary.

An independent coder was used to analyse the data, and the themes and sub-themes were finalised through consensus discussion. Literature control was used to verify these findings. Guba's model of trustworthiness (in Krefting 1991:212-216) was utilised to ensure trustworthiness. The criteria used for trustworthiness were credibility, transferability, dependability and confirmability (see Table 1).

\section{ETHICAL ASPECTS}

The researchers utilised the following standards as a guide throughout the research study:

- Freedom from harm: All participants in the research study were protected from any physical and psychological harm, and were informed of the possible impact of the study. The researchers ensured that participants were protected by informing the fieldworker fully, which included explaining to him that the participants were allowed to withdraw from the study at any time, should they feel uncomfortable.

- Informed consent: It is essential for a researcher to obtain informed consent from the participants (Strydom \& Venter 2002:74). The researchers achieved this by explaining to the prospective participants what the goal of the study was, and explaining the methodology, steps to ensure anonymity and 
TABLE 1

Strategies to ensure trustworthiness

\begin{tabular}{|c|c|c|}
\hline STATEGY & ACTIONS & APPLICATION CRITERIA \\
\hline \multirow[t]{7}{*}{ Credibility } & $\begin{array}{l}\text { Prolonged and } \\
\text { varied field } \\
\text { experience }\end{array}$ & $\begin{array}{l}\text { - } \quad \text { Contact was made with the participants prior to the interview to build rapport with them } \\
\text { The researcher (overseeing the fieldwork) had twenty-eight years of nursing experience } \\
\text { and had specialised in AIDS care and palliative care for five years } \\
\text { The researcher (mentioned above) had gained insight into the context in which } \\
\text { participants experience the nursing of patients who have AIDS and are dying of AIDS } \\
\text { The research supervisors had years of experience in qualitative research and more } \\
\text { than twenty years each of nursing experience }\end{array}$ \\
\hline & Reflexivity & $\begin{array}{l}\text { - For purposes of reflection, the field worker (responsible for conducting the interviews) } \\
\text { made use of a journal and a diary } \\
\text { The researchers used this diary to check for biases } \\
\text { The researcher reflected on the content of the journal and diary during data analysis } \\
\text { and processing of the data }\end{array}$ \\
\hline & Triangulation & $\begin{array}{l}\text { Data were collected from different participants through unstructured interviews and field } \\
\text { notes (Triangulation of data sources and methods) } \\
\text { Data were to be verified by literature control (Theoretical triangulation) } \\
\text { The researchers and independent coder experienced in qualitative research analysed } \\
\text { the data (Triangulation of investigators) }\end{array}$ \\
\hline & Peer examination & $\begin{array}{l}\text { Discussions were held with nursing colleagues who had experience in palliative care } \\
\text { nursing and HIV/AIDS care } \\
\text { Independent checking of data was done by experts in qualitative methodology }\end{array}$ \\
\hline & Authority of researcher & $\begin{array}{l}\text { - The researcher overseeing the fieldwork had five years of experience in the field and } \\
\text { was familiar with the phenomenon being studied } \\
\text { The researcher (overseeing the fieldwork) received postgraduate training in research } \\
\text { methodology and was familiar with qualitative studies } \\
\text { The co-authors had extensive experience in conducting qualitative research } \\
\text { A pilot study was conducted to increase the researcher's confidence in research } \\
\text { methodology }\end{array}$ \\
\hline & Interviewing technique & $\begin{array}{l}\text { - } \quad \text { All the participants were asked the same research question to determine whether a } \\
\text { logical rationale was present } \\
\text { In-depth interviews with a phenomenological approach were conducted } \\
\text { Open-ended questions were asked } \\
\text { - Verbal and non-verbal skills were used to encourage participants to talk freely }\end{array}$ \\
\hline & Structural coherence & $\begin{array}{l}\text { - The researchers ensured that there were no inconsistencies between the data and its } \\
\text { interpretation } \\
\text { The participants' experiences of nursing patients who had AIDS, and who were dying } \\
\text { from AIDS, were the main focus of the study }\end{array}$ \\
\hline Transferability & Nominated sample & $\begin{array}{l}\text { - A purposive, criterion-based sample was selected from the available participants who } \\
\text { were working with patients dying of AIDS } \\
\text { The researcher (overseeing the fieldwork) set sample criteria } \\
\text { A dense description was given of the results with supporting, direct quotations from the } \\
\text { interviews with the participants }\end{array}$ \\
\hline \multirow[t]{3}{*}{ Dependability } & Dense description & $\begin{array}{l}\text { A detailed description of the research methodology, including literature control, was } \\
\text { provided to maintain clarity } \\
\text { The dense description was written in such a manner that another researcher would be } \\
\text { able to follow the proceedings of the study } \\
\text { Guidelines were also discussed }\end{array}$ \\
\hline & Triangulation & Described above \\
\hline & Peer group evaluation & Described above \\
\hline \multirow[t]{3}{*}{ Confirmability } & Field notes & Personal logs and field notes were kept \\
\hline & Triangulation & Triangulation as described \\
\hline & Reflexivity & Described above \\
\hline
\end{tabular}

As adapted from Krefting (1991:214-222)

confidentiality and their right to withdraw from the study at any time. Consent to conduct the research was obtained from the Executive Committee of the institution where the research was undertaken and from the University's Research Committee.

- Anonymity and confidentiality: According to Strydom and Venter (2002:65), research subjects have a right to privacy. The researchers ensured this by not revealing the names of the participants, conducting interviews privately in a room set aside for counselling, and wiping the cassettes clean following the writing of the research report.

\section{OUTLINE OF THE RESULTS}

One central theme and five sub-themes emerged from the analysis of the transcribed interviews and the consequent consensus discussion held between the researchers and the independent coder. Table 2, below, provides an outline or overview of the theme and sub-themes.

DISCUSSION OF THEMES AND SUB-THEMES

Central theme: In their daily line of duty, caregivers experience various challenges as a result of having to deal with the death of their patients suffering from AIDS

During discussions between the examiners of this study, the coexaminer and independent coder and the researcher, the many different experiences that were shared by the participants were summarised as set out under the above-mentioned theme. These experiences are as varied as the nature of the work that these caregivers are called to do and are related in the course of the following summaries of the themes. 
TABLE 2

Identified theme and sub-themes related to the experiences of caregivers in palliative care institutions offering care for terminal AIDS patients

\begin{tabular}{|c|c|}
\hline CENTRAL THEME & SUB-THEMES \\
\hline \multirow[t]{5}{*}{$\begin{array}{l}\text { In their daily line of duty, caregivers experience various } \\
\text { challenges as a result of having to deal with the death of } \\
\text { their patients suffering from AIDS }\end{array}$} & $\begin{array}{l}\text { Sub-theme } 1 \\
\text { Caregivers experience emotional challenges in caring for patients dying of AIDS, which include: } \\
\text { 1.1 Difficulty and fear in accepting death. } \\
\text { 1.2 Sadness and pity when a patient dies. } \\
1.3 \text { Anger towards relatives who do not visit patients. } \\
1.4 \text { Helplessness and distress at not being able to alleviate the suffering when patients are dying. }\end{array}$ \\
\hline & $\begin{array}{l}\text { Sub-theme } 2 \\
\text { Caregivers experience a difference in the death and dying of adults as opposed to that of children: } \\
2.1 \text { Caregivers appear to avoid bonding with those that are destined to die. } \\
2.2 \text { Caregivers experience adults as having a role in acquiring this disease. } \\
\text { 2.3 Caregivers appear to be more comfortable with adults dying than with the death of children and babies. }\end{array}$ \\
\hline & $\begin{array}{l}\text { Sub-theme } 3 \\
\text { Caregivers experience the rationalisation of death and dying differently: } \\
3.1 \text { Caregivers describe death as God's will. } \\
\text { 3.2 Caregivers experience the process linked to death as fascinating or intriguing. } \\
\text { 3.3 Caregivers experience that working with People living with AIDS (PLWAs) has enabled them to grow mentally and } \\
\text { spiritually. }\end{array}$ \\
\hline & $\begin{array}{l}\text { Sub-theme } 4 \\
\text { Caregivers experience that faith in God gives them strength to cope with death and dying: } \\
4.1 \text { Caregivers experience that God provides hope and faith. } \\
4.2 \text { Caregivers experience death as a reality of life. } \\
4.3 \text { Caregivers experience prayer as an integral measure of strength. }\end{array}$ \\
\hline & $\begin{array}{l}\text { Sub-theme } 5 \\
\text { Caregivers experience caring for patients as fulfilling and meaningful to them, despite the sadness of death and } \\
\text { dying, which includes the fact that: } \\
5.1 \text { Caring so much for the patients emotionally and physically has the result that there are no regrets when the patient } \\
\text { dies. } \\
5.2 \text { Working with terminal PLWAs provides a positive contribution towards the patient's last days. } \\
5.3 \text { Being in constant contact with death and dying reaffirms an appreciation for being alive. }\end{array}$ \\
\hline
\end{tabular}

There is little doubt, from various studies, that caregivers experience difficulties in caring for patients dying of AIDS. These difficulties include fear of contagion, reactions to repeated exposure to death and dying, plus feelings of helplessness, grief and loss (Hertz 1994:1). The problem with dying patients is that they no longer fit into the total societal system, in that they cannot be healed, which leaves the caregivers with a dilemma, since the whole point of the health care system is to heal (Hertz 1994:1). Most health care facilities are vague about the concept of death, preferring to speak around the word instead, which highlights the inability to deal with something that preferably is not discussed, so there is a form of denial regarding death which is further emphasised in the language used by caregivers and other health care workers. Medical personnel tend to use words such as 'expired' and 'passed away' to describe death (KüblerRoss 1975:10) and this tendency is echoed in the words of two caregivers:

'...and then I knew that she was going and that evening she passed away. You know, it's like that...

'No we don't say "died", it's so...dead, it's so, disrespectful. I shall say, "passed away" would be a more appropriate word.'

There is insufficient documentation on the effects of caring for those dying, especially on the unprecedented scale that we are currently witnessing, and there clearly is no 'best way' to cope with death; there is only the way that all people develop, as a manner of 'coming to terms' within their capacity, at any given moment (Ahmed 1992:168).

'You know what, we used to have three in one day, three corpses in a one day sometimes, you know. If the whole week ends up in there's nothing then we say: "Thank you Lord".'

'Oh, it's stressful, it's a stress. You know, this is not a thing you can say you get used to, you know you can't, it's a stress to see people going, you know, one after another...one after another.'

Adding to the challenges for the caregivers is 'anticipatory grief', since it is known to all of them that $95 \%$ of adult patients who are admitted will die; it is only the time frame that varies from patient to patient. The caregivers, therefore, consciously or unconsciously, are waiting for their patients to die, which further entails working through the grief process for each patient and learning to work through the anticipatory grief, which includes changing assumptions (from assuming that the patient will recover to accepting death as inevitable) and finding a balance in remaining separate from, yet involved with, the patient (KeeneReeder 2003:2).

Numerous studies related to caregiver burden, depression, stress, and coping emphasise coping with stress, but what needs to be considered currently, especially with the AIDS pandemic, is how personal suffering may influence the caregiver's emotional health (Marwit \& Meuser 2002:1). 'Difficulty dealing with grief was ranked as tenth on a list of 30 care giving challenges, which suggests that grief reactions play a tangible, yet often overlooked, role in caregiver stress' (Marwit \& Meuser 2002:1)

'I really feel sad for them, to see someone dying and you can only do your $20 \%$ or $50 \%$. That's all. You feel...can't I do more? ... That is to feel totally helpless.

'Some of the things that make me sad...to see someone really ill, and there's actually nothing you can do...just make the last few months or days as comfortable as possible you can make for them. That's all. It's really touching...it's really sad.'

There is no amount of knowledge that can prepare us for bereavement of any kind, and there are no quick fixes for grief, which is part of a cycle; the only way out is through it and each one finds his or her way at his or her own pace.

\section{Sub-theme 1: Caregivers initially experienced emotional challenges in caring for patients dying of AIDS}

If even professional nurses caring for patients with AIDS experience a sense of futility in nursing patients destined to die, how much more so do caregivers who do not benefit from basic training in nursing?

\section{Sub-theme 1.1: Difficulty and fear in accepting death}

Death is one of the hardest things that a human being faces and it never fails to invoke a myriad of emotions in those close to the dying person. What does one say to a dying person? This is where the problem lies, where a conspiracy of silence surrounds the dying person because it is easier to be silent and deny the impending death than to face it (Youll 1989:88-94). Most caregivers interviewed acknowledged that the concept of death was difficult to discuss: 
'It was, like, the way I thinking of death it was like, what happens after that? Why are they dying? It's like, can it happen to me? Will there be pain? That's only what scares a person, how will it feel?'

'Death is terrible, because you don't know what happens after death... that is why you are scared, because you don't know [what's] happening during death.'

Despite the above sentiments, fear of death is not considered as undesirable as it seems in those who are involved in caring for the dying, in fact fear of death may well be psychologically unavoidable, and it may in fact be considered impossible to render care to the dying without the caregivers candidly and honestly acknowledging their fear of death (Nokes 2000:3)

\section{Sub-theme 1.2: Sadness, and pity when a patient dies}

'Working here, it's very difficult at times, not always. Sometimes you feel sad, helpless and angry emotionally.

'The patients, it affects me, because when I look there I saw them through pains, so I... I feel very bad, when I saw them in pains, I help them very much because I feel very pity of them.

In a study by Smit (2003:9), many nurses were reported as stating that they felt extremely emotionally drained through having to help their patients who were dying of AIDS, especially due to the suffering imposed by the disease, and the process of dying a protracted death, which occurs with most patients.

\section{Sub-theme 1.3: Anger at relatives who do not visit patients}

Social support, particularly from family, is integral to the wellbeing of all patients, and aids in recovery or a peaceful death. Poor and Porrier (2006:2830) state that in the case of AIDS patients it is imperative that their family and friends support them to enable them to cope with the progress of the disease and the inevitability of death. Regrettably, in far too many cases the family abandons the patients, possibly due in part to the stigma that surrounds AIDS, cost of caring for these patients, and the inability to deal with the suffering caused by the disease.

'You know people outside will say "ja you're just working with those AIDS patients", to them AIDS is so "ugh! It can't happen to me."'

This is a tragic occurrence that has serious effects on the patients, as well as on staff members who observe the patients hopefully waiting for a visit, which would prove that the patients have worth and are still loved and cherished despite the unlovely disease.

'You know another thing, that one day if more patients will come; the only thing that I would like to see is the family's response and the family support to give to these patients.'

'I've experienced that sometimes you have to phone to remind them, "HULLO! One of your relatives is here, can you please come in and visit?!"'

Caring for the patients is hard work; having to become substitute family adds to the daily tasks of the caregivers, which does make them angry when they consider the needs of their patients, for whom they care deeply:

'Mostly they need love because most of them don't get love from their families and some are neglected by their families.'

The caregivers interviewed realised what many books and articles have pointed out; that all people with a terminal illness really need in order to cope at all is love and acceptance and it makes them feel angry when their patients do not receive this from their families.

Sub-theme 1.4: Helplessness and distress at not being able to alleviate the suffering when patients are dying The impact of AIDS is overwhelming and most caregivers feel rage against the total ignorance and bigotry of those who do not acknowledge the severity of the disease regarding those on whom it impacts most - those with the disease and their loved ones (Kain 1989:276). This causes feelings of despair, distress and anger (Kain 1989:277):

'I talk to God, I ask Him to save these people, I know that if He like to He can save them, I just wish He can save all of them so they can't die.'

Working with deteriorating patients who do not benefit from recent treatment advances can result in feelings of helplessness, anger, frustration and depression (Demmer 2001:40).

\section{Sub-theme 2: Caregivers experience a difference in death and dying for adults as opposed to children}

'A child's terminal illness and/or death is an almost unspeakable, and a rare, tragedy; in the developed world the death of a child is considered as affront to the natural order because parents are not supposed to outlive their children.'

(Levetown 2006:1)

'I feel very bad, sometimes I cry when a baby dies, because this little child, he don't know nothing, he don't know nothing about life.'

'I feel sorry about all the death, especially the children, because they don't know what is happening to them.'

There is a possibility that the caregivers interviewed, while perceiving a difference between adult and child deaths, are inclined to consider this subjectively, from their personal feelings that suggest that it is more natural and better for adults to die than children:

'I feel very, very painful when a child dies; it's better the adults.'

'If a child dies or suffers, it's like, why? Why him? Why not the parents? Why not someone else? Why was it this child?'

When the caregivers identify to such an extent with their patients, particularly children, there is a danger that, when the child dies, the caregiver will grieve as if she has lost her own child. One caregiver said:

'Ah with the children dying, it's quite traumatic for us because most of the children that come here are orphans and some of them don't have anybody else around them when they die, except for us, the staff.'

There is no doubt that a primary stressor for AIDS caregivers is dealing with dying patients; having to cope with the death of babies and children clearly compounds their stresses.

Sub-theme 2.1: Caregivers appear to avoid bonding with those that are destined to die

In order to care for people one has to experience loss oneself and then create and maintain one's own balance (Alaniz 2001:2). Many caregivers become physically and emotionally drained by their experiences, which results in burnout. The results of the above could be to become toughened and emotionally cold, which is a means to survive both psychologically as well as materially (King 2002:2).

The following excerpt from a transcript underscores the fact that caregivers avoid bonding with those who are destined to die:

'No favourites (babies). I had, I had. And the baby passed away. But now for me, everyone is my favourite. I can't have one, all of them is my favourite, I see to that.'

When asked if she avoids bonding with the babies to protect herself from further hurt, she replied:

'I think so, ja, because I get very attached to people, very, and babies, very easily. Don't want to sit with that broken heart again. It's so sad, and it's too painful. And it's too sad, Ah, they're all so sweet.

When asked how she felt when she was informed that the baby discussed above had died, she answered:

'I was, I was angry. I was heartbroken, and stressed out. I thought if I'd got the night shift maybe things would have been so, maybe 
if they'd checked, it would have been so, or stuff like that; it made me very angry.'

Alaniz (2001:3-5) confirms this sub-theme by pointing to the fact that the anxiety (stress) experienced by caregivers in coping with dying patients is subconsciously transferred to an unwillingness to become attached to any more children, even the ones they might naturally bond with.

\section{Sub-theme 2.2: Caregivers experience adults as having a role in acquiring this disease}

Caregivers experience adults as having a role in acquiring this disease. This is linked to the stigma and discrimination associated with the disease, and many of the caregivers share the belief that adults could avoid contracting this disease. One articulated it as follows:

'If I must go into that, then you have to face the consequences of whatever the way you live, because that's what they chose. I say whatever you sow, you will reap.'

The impact of stigma is devastating; those dying of AIDS need love and care, but they are stigmatised (Bond, Chase \& Aggleton 2002:6).

Sub-theme 2.3: Caregivers are more comfortable with adults dying than with the death of children and babies

According to Stajduhar (1998:15), caregivers nursing AIDS patients describe their work as 'overwhelming, ongoing, and never-ending'. Especially poignant is the resilience of children in that they appear critically ill one minute and the next moment they rally and want to play. This could cause the caregivers to be distressed when the child dies, because they might have expected that the child was recovering, which made them happy, and then the child suddenly dies. The recollection by a participant underscores this:

'When they told me that he'd died (five-year-old child), I went from shock to disbelief. In my head I was saying "but you don't understand, he wasn't supposed to die, and not now. This morning he was sitting up in a wheelchair eating porridge, he smiled at me, he smiled at me, it was a recovery look, that was not the look of someone who is going to die today, how can you tell me he's dead?"'

Caregivers are clearly uncomfortable about a child dying, which causes more problems for the child who might need to air his feelings, fears, and questions about what is happening. The caregivers also expressed the thought that they are unhappy about the death of children because it is not their fault that they are ill. The following utterance by a participant is provided as confirmation of this:

'Because these children are here; they don't even know why. They don't know that they are sick and that worries me, and I get worried because these children are dying just because of their parents. It's not them, it makes me angry, you must condomise, but it makes me angry, because these children, it's not them, it's the parents.'

\section{Sub-theme 3: Caregivers experience the rationalisation of death and dying differently}

The participants all appeared to use a form of rationalisation as a means of coping with death and dying. Although most caregivers interviewed indicated a reasonably positive outlook about death and dying, it does appear as though the caregivers, in order to deal with this constant awareness of death, do use rationalisation as a form of survival in an otherwise too-difficultto-contemplate situation. Rationalisation, like denial, comes across as avoidance of the word 'death', as is witnessed in the following utterance by a participant:

'I was helping with communion and the bread would not go down, I had to give her some water, and then I knew that she was going, and that evening she passed away. I immediately distance me, you know, because the person is busy going.'
All of the caregivers interviewed have rationalised death, some by avoiding it, some by using phraseology to make it sound better and some by deciding it is God's will, as discussed under sub-theme 3.1 .

Sub-theme 3.1: Caregivers describe death as God's will God's will is often referred to in cases of personal tragedies and disasters, when the event is rationalised by saying nothing could have been done to prevent the occurrence, it was God's will. The following statements made by participants underscore this subtheme:

'Okay, it is sad if I see a patient dying, or a child, but for me, it's like God's decision.

'From nursing and loving the child it was just something that you need to tell yourself, that the child has passed away. There's nothing that you can do, you can't take the Lord's work out of His hands, and you have to go on with life, because life goes on.'

Perhaps viewing death as God's will - whilst being a rationalisation, a means of coping - could also be viewed as a way of locating death in a larger cycle of life or of nature.

\section{Sub-theme 3.2: Caregivers experience the process linked to death as fascinating/intriguing}

It has been said that the public is fascinated by death and patients themselves speak of their fear coupled with fascination (Levy 2001:2038). Fascination with death could also be a defence mechanism, a way of intellectualising death to avoid the emotional side. The following quotations point to the fact that the act of dying is fascinating:

'Wow! It's amazing, amazing how quick can a person be swept away from here, and you still communicated with that patient in the morning, understand?'

'You just sit next to them, and they know that they really are going now, and they frightened to go, they sometimes scream, cry, and then moaning sounds and then they gasp off. It's like, something amazing to see.

Fascination with death could be yet another form of rationalisation, since rationalisation is an unconscious response to anxiety, which accompanies fear, both of which are natural responses to death, so that it could be that fascination with death covers fear and enables the person to cope with death.

Sub-theme 3.3: Caregivers experience that working with PLWAs has enabled them to grow mentally and spiritually

Health care workers in the AIDS field continually strive to meet the physical, emotional and spiritual needs of the dying and their grieving families, which leads to personal growth in these workers, as one participant so fittingly stated:

'I have grown up mentally and physically and it's really strengthened me, inside of me, really.'

However, the former utterance could still be a form of rationalisation in that it would be natural for the caregivers to feel that they have grown, rather than that they are heading for burnout, as the participant quoted above indicated later in the interview:

'My spiritual need is now lying on the rock, like I'm not discouraged but, when I go to church, it's like, why am I sitting here? You know, it's those type of things, and then I think why doesn't the Lord take me, quickly? Why do I still need to face those people and stuff like that, you know?'

Although this might not signify full spiritual growth, it does show an awareness that all is not well, which is an acknowledgement of spiritual discomfort, which is a form of growth. Very little research is available pertaining to educational or training interventions that could help caregivers enhance their spirituality in a way that would enable them to meet the needs of dying patients adequately (Koenig 2002:6). 
Sub-theme 4: Caregivers experience that faith in God gives them strength to cope with death and dying

All the participants indicated that the only way that they could get through their working day, and indeed work in this environment at all, was due to faith in God. Spiritual beliefs were said to heighten job satisfaction and mitigate stress, especially when working with AIDS patients (Hoare \& Nashman 1994:185).

One participant confirmed the aforementioned when she said:

'Yes I believe my faith is strong and is really something that I can depend on. I believe in God.'

However, many of the caregivers interviewed tended to contradict such statements (of faith) with statements depicting hopelessness and helplessness, as illustrated by the following utterance from a participant:

'Death became all encompassing, everything in my mind was about death, there was so much death it's all I could think about.'

Questioning her about how she managed to continue with her work with such feelings, she said:

'Spiritually I had to ask the Lord really to strengthen me inside, because it will kill me afterwards, and continually I will think of it [death] ... Matron is giving this little Daily Faith Bible, I would just open it and that little verse would say a lot to what is going on in my life and I would feel much better. Those books help me a lot if you are feeling down, depressed and miserable.'

If faith in God is cited by caregivers as enabling them to cope with the difficulties of dealing with death and dying, this, indeed, is in keeping with the literature, which points out that healthy spirituality has been identified as being associated with a long, healthy life, while the opposite is equally true (Cochinov \& Cann 2005:S107)

So, while there are many comments from all the caregivers interviewed about faith in God, which helps them to cope it appears that the many contradictions also speak volumes concerning the inner conflict, turmoil and spiritual pain experienced by caregivers, which can only escalate if not treated adequately.

\section{Sub-theme 4.1: Caregivers experience that God provides hope and faith}

Faith does not prevent the inevitability of death or the pain of grief, so how can caregivers cope? They need to ensure that they receive spiritual care, and that includes asking religious leaders for help, especially when trying to make sense of death, dying and the grieving process. One participant spoke about asking religious leaders for help and said:

'It does help me if I speak to somebody, I usually speak to one of our Reverends at my church and he always shows me what to think or say.

Bereavement is one of life's greatest stresses, and the more bereavement people face, the higher the stress, therefore caregivers need to learn how to de-stress, so that they may be in a position to help their patients.

Many of the caregivers attested to their belief in God and their hope in the death and resurrection of Jesus Christ. The following quotation bears testimony to this:

"Ja, the other side is right because I am going to rest and wait for my God, my Jesus.'

Studies have shown that those who attend church were quite likely to have made a religious commitment, which is further hypothesised to lead to improved stress-control mechanisms, rich social support and the strength of personal values (Puchalski 2001:2).

Sub-theme 4.2: Caregivers experience death as a reality of life

There is no doubting the reality of death, and in this AIDS crisis everyone needs faith to cope with the magnitude of death. The caregivers who were interviewed for the current research readily attested to this fact, they have all seen enough dead people to be sure of this reality, which was expressed by one caregiver who commented:

'You know, with the death, coping with the death, I am a very emotional person, but I started becoming like death. It's like there's something that gets to me, I think. I can't walk away from it.'

That AIDS causes immeasurable suffering is undisputed, but God's presence with those who are suffering is equally clear to both the patients and staff at this place of work. Those who care for the infected experience God working with them to enable them to overcome the suffering that is being experienced. Pain and suffering in a dying person is terrible and tears at the heart, leaving us numb, desperate and frustrated (Kelly 2006:5).

'When he had fits of pain that no amount of morphine could control, he screamed out 'momma' with such intensity, such anger that I felt totally inadequate; here was a five-year-old boy, orphaned, abused, in pain, and dying of AIDS.'

It does not get more real than this, but somewhere in all the suffering, it is important to believe that the person eventually passes to a new stage of peace and acceptance (Kelly 2006:5).

\section{Sub-theme 4.3: Caregivers experience prayer as an integral measure of strength}

Prayer is our communion with God, and all the caregivers interviewed spoke of prayer as being the one thing that got them through the day. The following confirm this sub-theme:

'I pray, I always pray, God gives me strength.'

'Crying and then praying. I go to a place alone in my room; I always call it my quiet place, to pray about it. Somehow or other, you do get peace.

Prayer is a powerful force in asking for and welcoming God's help. God is present to aid us in the healing process, to support us in our time of illness, crisis or need (Rauch 2000:3).

Belief in the power of prayer, along with faith and the strength received from God through prayer clearly are of immeasurable help and comfort to the caregivers who are working with dying adults and children in this place.

Sub-theme 5: Caregivers experience caring for patients as fulfilling and meaningful, despite the sadness of death and dying

Although there is a lack of data on the prevalence of the burnout syndrome amongst AIDS caregivers in developing countries, studies have highlighted extensive depression, anxiety, overwork and fear of death (Prabha, Jairam \& Amila 2004:4854). In the palliative care setting, burnout is also viewed as a coping mechanism used by caregivers to distance themselves emotionally from the patients to enable them to continue working in the field, which implies that burnout could be a state of being rather than a process (O'Neill \& McKinney 2003:6).

'Working here is very difficult at times, not always. Sometimes you feel hopeless, angry emotionally. Those things can be caused by the stress that you come across of not coping to help your patients.

The caregivers interviewed for this study mostly expressed how well they care for the patients and cope with the inevitable death of patients, but the researcher wondered whether there was not a degree of denial on the part of many caregivers, with their not being aware of how deep their emotions were and to what extent they were denying their true feelings. Burnout has been described as being

a syndrome of emotional exhaustion, a depersonalization and reduced personal accomplishment as a result of chronic emotional strain of working extensively with other human beings, particularly when they are troubled.

(O’Neill \& McKinney 2003:6) 
This came through in one of the interviews:

'Yes for that matter I got many, more than five counsellings from Matron, she gave me the counselling. She helped me a lot because I have been crying and depressed.

Most of the caregivers spoke about how wonderful their work is, how much they have grown and how death does not affect them, saying that they are content with the fact that the patients must die, but such statements were contradicted throughout the study by others who spoke of the pain and suffering observed and how hard it was to deal with this every day. This led the researcher to explore the possibility of burnout in many of the long-term staff members.

'Okay, it is sad for me if I see a patient dying, or a child, but for me, it's like God's decision. If He feels you must go now, then it's your time to go,' was a statement made by one of the caregivers.

Later in the interview this same caregiver stated:

'It does make me sad, when they die. I'm even worse with the children; I don't know how I will cope when a child dies while I'm working in the nursery.'

Despite the enormity of their task, however, and the obvious emotional toll that it takes on the caregivers, the workers still succeed in feeling positive most of the time:

'I like to look after the patient; I know what's happened to the patient whence they are adults. I like to help the people, you know, the sick people.

Therefore, despite the negative factors and the potential for burnout, there are rewards of care giving, such as:

- Providing a mission and a sense of purpose to one's life

- Development of empathy and self knowledge

- Gaining a sense of personal effectiveness by demonstrating competence under very difficult circumstances

- Experiencing the positive feelings associated with loving, caring and feeling needed (O'Neill \& McKinney 2003:6).

The researcher definitely saw many instances of such positive growth in the caregivers in this institution, despite knowing of at least five caregivers who had shortly before started taking antidepressant medication, following referrals by the institution to the doctor who usually assists with patients.

Sub-theme 5.1: Caring so much for the patients emotionally and physically has the result that there are no regrets when the patient dies

Caregivers in other studies have stated that they find working with AIDS patients rewarding and that such work gives them a sense of fulfillment. Making patients comfortable and supporting a patient emotionally, especially at the time of death, also enhances the work experience for these caregivers (Stajduhar 1998:14).

'But when she dies it helps me because I feel proud. I saw her suffer and then I help in so many things, you know, with love and caring.'

'And if you do what you must do while you [are] around the person then it gives you that satisfaction, you did what you could.'

What is important is that the mourning process is easier for caregivers when they know that they did a good job caring for their patients by giving them respectful, compassionate care. AIDS has compelled many people to face their own mortality, many have died, many live with the infection, and all who work on the front line have learnt about the temporary nature of life (Goldblum \& Erikson 1999:2).

The caregivers in this study tried their best to reach out to all of their patients and thus avoid regrets when the patient died, but this was not always possible, and was vocalised as follows:

'When you are not able to help somebody sometimes you are working alone on the adult side and there also another person that wants help, you will feel angry that, eh, I wish that there was somebody who can help that one, because I am still busying here with this one."

Caring for dying children is exceptionally stressful, especially when one observes them suffering. Although advances have been made in understanding the impact of death and loss, too little has been done to apply this knowledge in preparing health care workers for the challenges of paediatric palliative care (Contro et al. 2004:3). Despite this, a number of caregivers who were interviewed felt fulfilled through ensuring that the emotional needs of the children were met prior to death, which left them with no regrets:

'I feel all right at least in his last time I did the thing he want, like he say to me, let me feed myself the porridge, and then I give him and then he sat and eat, just feel that I, I did do something that he wants before he goes.

The staff needs to be reassured that they really are doing their best, and that they are doing all that they can for their patients (Contro et al. 2004:7). The need for debriefing therefore is clear, in order to support caregivers and enable them to cope with accepting their limitations and to have some peace in knowing that they did a good day's work and that they could not have done more, to avoid the following type of comment:

'Did we do enough? I started to think like that and that makes me feel bad, you know, we always had that guiltiness that maybe there is something that I didn't do.'

Sub-theme 5.2: Working with terminal PLWAs provides a positive contribution towards the patient's last days

The following utterance by a participant confirms this subtheme:

'If you must leave this place or you go somewhere else, you can go with a positive thought and mind and tell them, listen; this is where I worked and the patients whom I cared for while there, it really is a marvellous place, really.'

Others were struggling with the workload and not feeling so positive:

'Working here is very difficult at times, not always. Sometimes you feel sad, hopeless, angry emotionally. These things are caused by the stress that you come across of not coping to help your patients.'

Much as the caregivers in this study tried to have a positive attitude, they did state the need for help in the form of debriefing, which would be a tremendous help in coping. The following refers to this:

'It makes it very hard for me to cope within this working place that thereby they will get stress, we need to have these eh, eh, mentors, we need to take two to five minutes of non-working activities so that we can breathe, voice out, you see. And we need mentors whereby you full; you have to talk to that particular person.'

This caregiver was aware of the need to have structured debriefing, some 'time out' and stress release, which would help the caregivers to continue to contribute positively to their patients' last days.

Some of the caregivers even attended the funerals of their patients, which apparently is not a bad thing. The caregivers clearly needed the closure that a funeral generally brings and it assisted in helping the caregivers to feel that they did all that they could for the patient, right up to honouring the patient by attending the funeral. The caregivers in this study were trying to give their best care possible, but they also had so many needs of their own, which were largely unmet, that it was hard to see just how effective they really could have been with their patients.

Sub-theme 5.3: Being in constant contact with death and dying reaffirms an appreciation for being alive

Caregivers in various studies have said that caring for those with AIDS was an intensely emotional experience filled with pride 
and enrichment and, conversely, with anger and disillusionment (Stajduhar 1998:20)

An indirect benefit of working with AIDS patients is coming to terms with the inevitability of death and the realisation that enables the appreciation of the benefits of death (Stajduhar 1998:17).

The following quotation from one of the transcripts concurs with the literature and supports this sub-theme:

'I've grown in this place; I embrace life more because of all the death that I have seen.

Many of the caregivers interviewed spoke of a belief in life after death:

'As a Christian I believe there is a life after this.'

Many caregivers assimilate their experiences and often make constructive changes in other aspects of their lives, or a change in how they view life (Stajduhar 1998:20).

'I personally, it has changed my outlook on life, it has changed, I would say some, some it makes you think, you know, I find that I grieve more when a relative dies, now, than before. I think it's due to all the death that we see here.'

Another indirect benefit of working with AIDS patients was identified as helping the caregivers to savour life and really appreciate being alive (Stajduhar 1998:17).

'It makes me treat people better, changed the way I see relationships,

like you know, arguments between my family, like I ask them do you know how short life is?'

Many caregivers are happy to be making a difference in their patients' lives when working with dying patients, and are definitely appreciative of being alive. There is no doubt that working in this field (HIV/AIDS) is very hard on these caregivers, especially due to the ages of their patients, therefore adequate and timely support is essential to assist these workers.

\section{BROAD GUIDELINES THAT WILL ENABLE THE MENTORS OF CAREGIVERS TO PROVIDE SUPPORT TO THESE CAREGIVERS}

These broad guidelines comprise two principal guidelines, namely: to create a work environment conducive to supporting of the caregivers, and to identify and enhance areas where support for caregivers can be instituted, which could help to prevent caregiver fatigue/burnout.

From these two principal guidelines, sub-guidelines were developed, which would assist mentors in formalising the guidelines. These included:

- Creating a physical environment conducive to optimal palliative care; this would include an exclusive restroom for the caregivers.

- Creating a supportive occupational environment conducive to enabling the caregivers to provide optimal palliative care for their patients. To achieve this, it is was suggested that management be facilitated to provide understanding, insightful and empathic support; that three-monthly counselling/debriefing sessions be instituted, and that caregivers be kept up to date concerning patient treatment and prognosis.

- Creation of an educational environment to enable the caregivers to provide optimal care for their patients who are dying of AIDS, which would be supported by the provision of in-service training for the caregivers and the development of a library in the ward.

- A description of caregiver fatigue/burnout should be utilised to ensure that signs and symptoms of this are monitored in all caregivers and strategies for preventing burnout and promoting self-care are instituted.

\section{LIMITATIONS OF THE STUDY}

As with all qualitative studies, it is recognised that the sample size and specific nature of the sample and research context prohibit generalisations. However, the richness of the data provided much insight into the experiential world of these caregivers. Specific limitations included the fact that interviews were conducted at one palliative care facility only and, secondly that although confidentiality was ensured as far as possible, participants could have been wary of sharing experiences due to concerns about this factor. This did not appear to be present in this research study.

\section{RECOMMENDATIONS}

In the light of the research findings and indicated limitations, the following recommendations for nursing practice, education and research were formulated:

\section{Recommendations for Nursing Practice:}

- The broad guidelines need to be made available to hospitals and clinics

- Management of institutions where patients with AIDS are being cared for need to be sensitised to the unique needs and challenges experienced by caregivers within the field of HIV / AIDS, to enable them to recognise it as an area of specialisation with scarce skills

- Guidelines need to be refined to develop a detailed support programme for caregivers working in the HIV / AIDS field.

\section{Recommendations for Nursing Education:}

- In-service education courses and workshops need to be developed to enhance the life-skills of care-giving workers with patients who are dying of AIDS. Palliative care is a specialised field, where research into the effects of working with terminally ill patients is current and ongoing. It is clear that anyone working in this field requires specific skills to cope with the arduous task of dealing with the death of their patients and then to be able to support the family and friends who are left behind. Due to the rapidity with which patients are dying, and the number of patients succumbing to this disease, education is crucial to enable caregivers to be empowered physically, emotionally and spiritually to cope with the death and dying of their patients.

\section{Recommendations for Nursing Research:}

- A questionnaire based on the themes identified in the interviews could be developed for use in a quantitative study, thereby testing the generality of the research findings of this study

- A model for explaining and predicting job satisfaction in HIV/AIDS nursing needs to be developed

- A model for predicting stress-response and coping mechanisms for caregivers working with patients who are dying of AIDS needs to be developed.

\section{CONCLUSION}

This research study explored and described the uniqueness of the challenges facing caregivers working at an institution that offers palliative care for patients dying of AIDS. Broad guidelines to enable the mentors of the caregivers to provide support to the caregivers, and thereby to enable them to optimise nursing care of patients dying of AIDS were formulated (as described above) on the basis of the research findings. If implemented, these guidelines would have a beneficial effect for both patients and staff.

\section{REFERENCES}

Ahmed, P.I., 1992, Living and dying with AIDS, Plenum Press, New York.

Alaniz, M., 2001, Lessons of loss, viewed 18 September 2006, from http://www.nurseweek.com/news/features/01-06/lessons. html. 
Allen, R.E., (ed.), 1990, The Concise Oxford Dictionary of Current English, 8th edn., Clarendon Press, Oxford.

Alexander, C., 2005, 'Palliative and end-of life care', viewed 1 November 2005, from http://hab.hrsa.gov/publications/ chapter12/chapter12.html.

Bond, V., Chase, E. \& Aggleton, P., 2002, 'Breaking the silence, ending the stigma, HIV/AIDS and prevention of mother-tochild transmission', viewed 5 September 2005, from http:// www.elsevier.com/locate/evalprogElsevier_1998.

Burns, N. \& Grove, S.K., 1997, The practice of nursing research, conduct, critique and utilization, 3rd edn., W.B. Saunders, Philadelphia.

Callanan, M. \& Kelley, P., 1992, Final gifts - understanding and helping the dying, Hodder \& Stoughton, London.

Chochinov, H.M. \& Cann, B.J., 2005, 'Interventions to enhance the spiritual aspects of dying', Journal of Palliative Medicine 8(suppl. 1).

Contro, N.A., Larsen, J., Schofield, S., Sourkes, B. \& Cohen, H.J., 2004, 'Hospital staff and family perspectives regarding quality of paediatric palliative care', viewed 4 October 2006, from http://paediatrics.aapublications.org/cgi/content/ full/1/4/5/1248.

Crabtree, B.F. \& Miller, W.L., 1999, Doing qualitative research, 2nd edn., Sage, Thousand Oaks.

Creswell, J.W., 1994, Research design: Qualitative and quantitative approaches, Sage, Thousand Oaks.

Creswell, J.W., 1998, Research design: Qualitative, quantitative and mixed methods approaches, Sage, Thousand Oaks.

Demmer, C., 2001, 'Dealing with AIDS related loss and grief in a time of treatment advances', American Journal of Hospice and Palliative Care 18(1), 36-38.

Eaton, J. \& Etue, K., 2002, The awake project: Uniting against the African AIDS crisis, W. Publishing Group, Tennessee.

Evian, C., 2000, Primary AIDS Care, CTP Book Printers, Johannesburg.

Goldblum, P. \& Erikson, S., 1999, 'Working with Aids bereavement: A comprehensive approach for mental health providers', viewed 4 October 2006, from http:// www.ucsf-ahp.org/HTML/bereaveintropro.htm (Accessed 4 October 2006).

Goodson-Dunlap, K., 2004, 'Psychological impacts of HIV/AIDS', independent study project, Nelson Mandela Metropolitan University.

Hertz, E., 1994, 'Three models of AIDS care in Denmark: Studies of patients' coping strategies, dynamics between patients/ staff and job strains', viewed 5 September 2006, from http:// gateway.n/m.nih.gov/meetingsAbstract/102210768.html.

Hoare, C.H. \& Nashman, H.W., 1994, 'Aids care in six Washington DC area hospices: Satisfaction and stress amongst professional caregivers', viewed 29 September 2006, from http://www.springerlink.com/content/q8852708444385X7.

Kain, C.D., 1989, No longer immune: A counsellor's guide to AIDS, American Association for Counseling and Development, Alexandria.

Keene-Reeder, E.A., 2003, 'A clinical guide to supportive and palliative care for HIV/AIDS', viewed 8 August 2006, from http://hab.hrsa.gov/tools/palliative/chapter16.html.

Kelly, M.J., 2006, 'Care of the caregiver: HIVAN Centre for HIV/ AIDS networking', viewed 28 September 2006, from http:// www.jctr.org.zm/downloads/faithaids.doc.pdf.

King, J., 2002, 'Care of the caregiver: HIVAN centre for HIV/ AIDS networking', viewed 18 September 2006, from http:// hivan.org.zm/downloads/faithaids.doc.pdf.
Keonig, H.G., 2002, 'The role of religion and spirituality at the end of life', viewed 25 September 2006, from http:// gerontologist.gerontologyjournals.org/cgi/content/ full/42/suppl-3.20.

Krefting, L., 1991, 'Rigor in qualitative research: The assessment and trustworthiness', American Journal of Occupational Therapy 45(3), 214-222.

Kubler-Ross, E., 1975, Death, the final stage of growth, Simon \& Schuster, New York.

Levetown, M., 2006, 'Children, caring for when life threatened or dying', Encyclopaedia of death and dying, viewed 25 September 2006, from http://www.deathreference.com/ce-da.

Levy, M.M., 2001, 'Paying attention to death', viewed 25 September 2006, from http://www.ccmjouranl/com/pt/re/ $\mathrm{ccm} / \mathrm{htm}$.

Maritz, J., 2003, 'A parent's experience of the couple relationship after child bereavement', M.Cur mini dissertation, Rand Afrikaans University.

Marwit, S.J. \& Meuser, T.M., 2002, 'Development and initial validation of an inventory to measure the grief in caregivers of persons with Alzheimer's disease', The Gerontologist 42(6), 751-765.

Nokes, K.M., 2000, 'Nursing issues in AIDS care', viewed 5 September 2006, from http://medscape.com/ viewarticle/418967.

O'Neill, J. \& McKinney, M., 2003, 'Care for the caregiver. A clinical guide to supportive and palliative care for HIV/ AIDS', viewed 5 September 2006, from http://hals.hrsa.gov/ tools/palliative/chap20.html.

Polit, D.F. \& Hungler, B.P., 1999, Essentials of nursing research methods: Appraisal and utilisation, 4th edn., Lippincott, Philadelphia.

Poor, B. and Porrier, G.P., 2006, End of Life Nursing Care, Jones and Bartlett, Sudbury.

Prabha, C.S., Jairam, K.R. \& Amila, J., 2004, 'Factors related to staff in HIV/AIDS related palliative care', viewed 2 September 2006, from http://www.jpalliativecare.com/ ariticle.asp.

Pulchalski, C.M., 2001, 'The role of spirituality in health care', viewed 28 September 2006, from http://pubmedcentral.nih. gov/articlerender.fegi?article $=1305900$.

Rauch, C., 2000, 'Probing the power of prayer', viewed 30 September 2006, from http://archives.cnn.com/2000/ HEALTH/alternative/01/18/prayer.power.wmd/.

Smit, R., 2003, 'HIV/AIDS and the workplace: The perceptions of nurses in a public hospital', unpublished study, Rand Afrikaans University.

Stadjuhar, K.I., 1998, 'Palliative care at home: Reflections on HIV/ AIDS family caregiving experiences', Journal of Palliative Care 14(2), 14-22.

Strydom, H. \& Venter, L., 2002, 'Sampling and sampling methods', in A.S. De Vos (ed.), Research at grass roots: For the social sciences and human service profession, 2nd edn., pp. 197211, Van Schaik, Pretoria.

Theodosius, R., 2005, 'AIDS baby horror at big PE hospital', The Herald, 30 May, p.8.

UNAIDS, 2004, 'Report on global HIV/AIDS epidemic', viewed 12 August 2004, from www.unaids.org/special/index/ html.

Youll, J.W., 1989, 'The bridge beyond: Strengthening nursing practice and attitudes towards death, dying and the terminally ill, and helping the spouses of terminally ill patients', viewed 5 September, from http://www.ncbi.nlm. nih.gov/entrez/query. 